\title{
Household Solid Waste Management in La-Nkwantanang-Madina Municipality of the Greater Accra Region, Ghana
}

\author{
Nkum Richard $^{1}$, Ampadu-Ameyaw Richard ${ }^{2}$, Antwi Boniface Yeboah ${ }^{3}$, Anderson Kwesi Ahwiren ${ }^{4}$ \\ ${ }^{1}$ Zoomlion Limited, Accra, Ghana \\ ${ }^{2}$ CSIR-Science and Technology Policy Research Institute, Agriculture, Accra, Ghana \\ ${ }^{3}$ CSIR-Institute of Industrial Research, Materials and Manufacturing Division, Accra, Ghana \\ ${ }^{4}$ University of Ghana, Faculty of Agriculture and Agribusiness, Legon, Accra Ghana \\ doi:
}

\begin{abstract}
Increased population, rapid urbanization and improved lifestyle have resulted in a rise in municipal solid waste generation that are difficult to manage. This paper explores the composition of household waste, the separation mechanisms, storage, and disposal methods. These were investigated as a way of identifying the different types of existing waste management practices and associated challenges through a survey of 196 households. The results suggested that the community of study was youthful, had a high literate population and therefore had the tendency to generate more waste through various economic activities in the community. The results showed that more than two-fifth of the waste generated in the communities of study constituted biodegradable organic waste. The door-todoor mechanism of waste collection was found to be the most employed in the communities. The data showed that, most of the households used dustbins in waste collection, nonetheless, limited access to the dustbins was observed as one of the major challenges of the community.
\end{abstract}

KEYWORDS

Waste separation,

Solid waste management,

Household wastes,

Dustbin,

Municipal wastes.

\section{CORRESPONDING}

\section{AUTHOR}

Antwi Boniface Yeboah boniface.antwi@gmail.com

Additionally, the respondents experienced irregular collection of the wastes, lack of dumping sites, and inadequate information on source segregation in the handling of generated wastes. Therefore, the study suggests the implementation of interventions, such as the supply of free dustbins to homes and the education of waste generators on source separation to enhance the effective management of the solid wastes in households.

\section{INTRODUCTION}

Waste management, particularly household solid waste management is one of the major challenges confronting governments all over the world. Several internationally and locally designed initiatives have been implemented to curb the impact of improper management of solid wastes. Yet, in spite of the numerous efforts by governments to alleviate or minimize impacts of poor waste management, the challenge seems to persist and even worsened in some communities in both developed and developing countries (Fobil \& Hogarh 2009). Effective control of waste generated in communities has not been achieved yet. This is in spite of the reality that inadequate management of waste is harmful to human health (Odonkor et al. 2020) in addition to the financial expenditure to the state.

In developing countries, it is estimated that per capita solid waste generation in urban residential areas has been high and paralleled that of 
developed countries (Amasuomo \& Baird 2016). In developed countries, per capita waste generation increased nearly three-fold over the last two decades, reaching a level, five to six times higher than that in developing countries (Ferronato $\&$

Torretta 2019). Furthermore, research shows that, in spite of the per capita rate of waste generation, the capacity of developing countries to collect, process, dispose, or reuse the solid wastes in a cost effective way is significantly reduced compared to the developed countries (Diaz 2017). Furthermore, (Diaz 2017), estimated that, should the current trend continue, global waste generation may see a five-fold increase by the year 2025 .

In Africa waste disposal is becoming problematic as every 9 out of every 10 African cities are facing serious waste disposal problems (Seth et al. 2014). This situation has often been attributed to improper planning, financial constraints, lack of motivation, and lack of enforcement of legislation to protect the environment and the people. While it has been observed that compositing is a great potential for waste minimization, these countries have often failed to reach the desired target. This has been attributed to inadequate support from state government and improper planning (Ayilara $\boldsymbol{e t}$ al. 2020).

An observation of the waste situation in some cities and towns in Ghana, including the current study area shows huge heaps of rubbish, and polythene bags that are scattered all over the municipality. Another challenge is the inadequacy of disposal sites, with the very few ones overflowing with filth, stench and flies posing a great danger to the people who leave around such places. All of these have been attributed to the irregular waste management services provided by waste collectors (Yoada $\boldsymbol{e t}$ al. 2014).
Ghana has a comprehensive policy on environmental sanitation which has been in existence since 2009 and 2010 (Alfaia et al. 2017). Yet, on the ground observation makes it evidently obvious that, state policies controlling and managing the solid waste have failed. There is therefore the need to have a relook at the existing policies and situation in order to have a remediation plan of action to rescue the cities from health and other environmental crises. To help address the issues, Government has initiated a number of reforms in the sub sector. This has included the decentralization of waste collection, which requires the private sector to take over state responsibility of controlling and managing waste in the cities and towns (Abalo et al. 2018). This move was inspired by efforts aimed at enhancing democratization and therefore 'modernizing' the state by allowing the state to create enabling conditions for the private sector to manage the waste. The expectation is that, urban solid waste will be effectively controlled. Yet this is far from the reality on the ground. The reality on the ground shows that, the government and private sector have not been able to respond in an equal measure to the rate of piles of filth in the communities (Ferronato \& Torretta 2019).

This study seeks to question why state policies have not been able to match the reality of waste management on the ground, in spite of all the reforms in the sub sector. While this study may not be the first of its kind on the subject, the context varies and therefore the results may vary. This assessment therefore calls for a better understanding of the situation on the ground by exploring the conditions unfolding in an urbanizing district. Results from this study will provide a sound basis for the design of measures intended to improve solid wastes management (SWM) in the Assembly and the nation. In this way, this study 
assesses the state of solid waste management in the Assembly by identifying and ascertaining consumers' viewpoints on the collection and disposal of domestic solid wastes in the $\mathrm{La}$ Nkwantanan-Madina Municipal Assembly (LaNMMA). This study specifically focused on ascertaining the composition of domestic waste, mode of separation at home, on-site storage types, and final disposal methods at home. It explored key challenges of solid waste management facing the people in the municipality as a way of addressing the emerging socio-environmental concerns of the municipality and by extension, the country at large.

\section{MATERIALS AND METHODS}

The study was conducted in the La Nkwantanang Madina Municipality in the Greater Accra Region of Ghana. The municipality has an estimated population of about 111.926 people (AdansiBonah 2016), which consists of a diversity of dwellers with over $84 \%$ of them being urban residents. It is one of the sixteen municipalities in the Greater Accra Region and was selected for study based on its recent increase in business activities and population growth which are likely to influence the SWM practices.

\section{a. Research design}

The research employed a case study approach to gather information for analyses. A random sampling technique was used to select communities of study under the municipalities as well as the households. Both qualitative and quantitative research methods were used for the data collection.

A face-to-face survey was conducted during the data collection.

The survey instrument covered questions around demographic information on respondents, the composition of domestic solid wastes, and the preferred mode for waste collection and separation mechanisms, as well as related challenges.

\section{b. Sampling and sample size}

Using the Cochran's (1977) (equation),

$$
n=\frac{\left(z^{2}\right) *\left(p^{2}\right)}{d^{2}}
$$

where, $\mathrm{n}=$ sample size; $\mathrm{z}=$ value for selected alpha level of each tail, $(=1.96$, the alpha level of 0.05 indicates the level of risk the researcher is willing to take that true margin of error may exceed the acceptable margin of error); $\mathrm{p}=$ estimate of standard deviation in the population, (unknown in this case but 0.5 or $50 \%$ was used for conservative estimate); $d=$ acceptance margin of error for mean being estimated $(=0.07$ with confidence interval of 93\%). From the equation, the calculated number of sample size for the study, was 196.

Substituting values into the equation gives:

$$
n=\frac{\left(1.96^{2}\right) *\left(0.5^{2}\right)}{0.07^{2}} \quad n=196
$$

The Cochran's equation was used due to its wide application in calculating sample size for continuous data to estimate representative samples (Tamrie et al. 2015).

\section{c. Data collection mechanisms and analyses}

A random sampling technique of assigning numbers to various households was used to select households for interviewing. The random sampling yielded $98 \%$ success as the interviewees found someone at home to interview them. Out of the 200 questions administered, the authors were able to use data from 196 questions. The questions on solid waste generated sought to identify the composition of the domestic wastes whilst questions on the mode of temporarily storage sought to identify the viewpoint of respondents on pre-disposal wastes 
sorting, and the allocation of waste bins for the separation.

The focused group discussions were employed to allow the survey participants to provide further and better understanding to information that the questionnaire was not able to capture in detail. That is, the group discussions with selected household respondents in the communities of study were used to validate and verify the quantitative findings, which were difficult to interpret from the preliminary results. Six focus group discussions were held during the filed data collection period. Each group constituted between eight to ten participants. With this approach, responses to a common question from all interviewees in each category were analyzed. The study employed manual compilation of data, using Microsoft Excel to tally responses and then exported resultant tally onto the Statistical Package for the Social Sciences (SPSS) version 18 platform for analyses. Tables of frequencies and calculated percentages were recorded and grouped.

\section{RESULTS AND DISCUSSION}

Demographics of the respondents was explored to characterize the population under study. The gender of respondents fell within $70.6 \%$ males and $29.4 \%$ females that closely corresponds to the gender distribution of the population in the study area, $70 \%$ males and $30 \%$ females. The majority of the respondents aged between 21 and 41 years old $(50.9 \%)$, with the least number of respondents below 20 years old $(2.7 \%)$. The adult population above 41 years old formed $46.4 \%$ of respondents. Furthermore, most respondents $(86.4 \%)$ exhibited literacy at different stages of the formal education ladder being $34.6 \%, 49.1 \%$ and $2.7 \%$ at the tertiary, pre-tertiary and basic school levels respectively. They worked in different professional fields being, farming (1.82\%), trading (45.45\%), public service (20\%), businesses (20\%), and other professions $(6.61 \%)$. Students formed $6.12 \%$ of respondents. This matches the Ghana statistical service records, which described the municipality as one inhabited by traders who carry out their businesses, mainly at the popular commercial center of the municipality, Madina market and its environs (Adansi-Bonah 2016).

\section{a. The composition of domestic solid wastes in the municipality}

Information on the composition of solid waste generated in a city is essential because it provides information that will aid decisions making by the municipal assembly and other agencies on the right techniques to adopt in the efficient management of the solid wastes (Sharma \& Jain 2019). For example, a high percentage in the amount of plastic wastes will inform managers on the need to promote recycling or reuse of the plastic for a reduction in landfilling (Sharma \& Jain 2020).

The most generated municipal solid waste was food waste $(45.3 \%)$ (Table 1$)$ which was consistent with literature (Abylkhani et al. 2020; Cheng \& Lin 2013; Miezah et al. 2015). This was followed by plastics (17.9\%) and the least, wood (2.4\%). Comparing the waste composition of the study area to similarly reported municipalities in Ghana, the estimated average figure for plastic wastes in LaNMMA was higher than $9 \%$ of the Accra metropolitan assembly (Fagariba \& Song 2016), $16 \%$ of Tarkwa municipality (Ansah 2014) and the national average of $14 \%$ (Miezah et al. 2015). However, the proportion was less than the $20 \%$ and $25.5 \%$ of the Tamale and Wa metropolis respectively (Amoah \& Kosoe 2014; Puopiel 2010). 
The increasing amount of plastic wastes in the various metropolis indicated a general phenomenon that required immediate attention from environmental management agencies and allied organisations (Alfaia et al. 2017). It was therefore needful that municipalities were encouraged to promote and implement source segregation (Yeboah et al. 2019) of wastes which captured the plastics at source for recycling and reuse purposes with a reduction in the leakages into the environement. The organics will go to composting companies or biofuel generators (Paritosh et al. 2018).

Table (1) Types of solid waste generated and their percentages.

\begin{tabular}{|l|c|}
\hline Component & Percentage by weight \\
\hline Food & 45.3 \\
\hline Plastic & 17.9 \\
\hline Paper & 8.0 \\
\hline Wood & 2.4 \\
\hline Metals & 9.1 \\
\hline Glass & 4.3 \\
\hline Textile & 9.5 \\
\hline Others, e.g. construction & 3.5 \\
\hline Total & $\mathbf{1 0 0 . 0}$ \\
\hline
\end{tabular}

Even though source separation is a relevant technique in managing generated wastes, households had minimal motivation to adopt the practice. For that reason, the respondents were asked about how they dispose the generated plastic wastes such as, sachet water bags, water bottles and polythene bags. Responses, Table 2, showed that, the plastics were either sorted $(50.91 \%)$ or mixed (49.09\%) with the organic wastes.

This indicated that, there was an appreciable amount of source separation amongst waste generators, who could be well informed or selfmotivated (Sarbassov et al. 2019). For instance, the respondents who separated the plastics derived motivation from the financial gains in the sale of the plastic wastes.

Table (2) Mode of plastic waste storage in homes.

\begin{tabular}{|l|c|c|}
\hline \multicolumn{1}{|c|}{ Mode of disposal } & Frequency & (\%) respondents \\
\hline $\begin{array}{l}\text { Separated from } \\
\text { other household } \\
\text { solid wastes }\end{array}$ & 56 & 50.91 \\
\hline $\begin{array}{l}\text { Mixed with other } \\
\text { household solid } \\
\text { wastes }\end{array}$ & 54 & 49.09 \\
\hline Total & $\mathbf{1 1 0}$ & $\mathbf{1 0 0 . 0 0}$ \\
\hline
\end{tabular}

The waste pickers or collectors sold the plastic materials to bulk buyers or agents of recycling firms. In addition, the non-biodegradability of the polymeric plastic material enhanced the reuse of the polythene bags and water bottles repeatedly in the households until they lost their utility value before donation to the plastic wastes pickers. Furthermore, the recovery of plastic wastes domestically contributed to a collective approach to harnessing the used resource for recycling and other purposes whilst reducing garbage pileups, post collection sorting cost and landfilling (Shen $e t$ al. 2020).

Additionally, the source separation of the plastic wastes and the sale, served as an alternative source of income for the households, which indicated the potential job creation opportunities embedded in the process of sorting, collection and recycling or reuse of the plastic waste resource (Miezah et al. 2015).

Mixed disposal of the wastes was prominent amongst the respondents due to prevailing factors such as, the lack of dustbins, storage space, and education or policy from the assembly on source separation. This shows that, the provision of education, dustbins and guidelines will enhance the separation of the wastes at the source.

Comparison between the LaNMMA and Bolgatanga, which displayed a $78.33 \%$ of mixed dumping over $20.56 \%$ source sorting, shows that, 
there was a common trend in the factors that influenced mixed disposal of the wastes in the municipalities (Miezah et al. 2015). In the case of Bolgatanga and other upper belt municipalities like Tamale, the absence of recycling companies acted as a disincentive for the source sorting which corresponded to the disposal of mixed solid wastes as the major form of waste management in the municipalities (Miezah et al. 2015). Therefore, the siting of recycling companies in the northern sector of the Ghanaian economy will promote source separation and sustainable solid waste collection.

\section{b. Methods of final household disposal of solid wastes.}

The final household disposal of solid wastes formed a phase in the waste management chain. In this phase, either the wastes were formally dumped in dustbins or they were sent to communal skips, or public dumpsites or given to bola taxi or truck pushers (Kaoje et al. 2017). Informally, some households buried the solid wastes in the ground, burnt them, or dumped the wastes in the open space (Fagariba \& Song 2016; Puopiel 2010).

The survey showed that, most households disposed their wastes in dustbins with $63.64 \%$ responses, which was followed by $11.82 \%$ for the skip method, (10\%) for the public dumping site and $(6.36 \%)$ for others, (Figure 1). Furthermore, about $4.55 \%$ burnt the waste whilst $2.73 \%$ of households buried them in the ground. A small proportion of households $(0.91 \%)$ indiscriminately dumped the solid wastes in opened gutters. This indicates that, the majority of respondents had dustbin in their homes whilst the rest had no dustbins for wastes collection and so they resorted to the other forms of disposing their wastes.

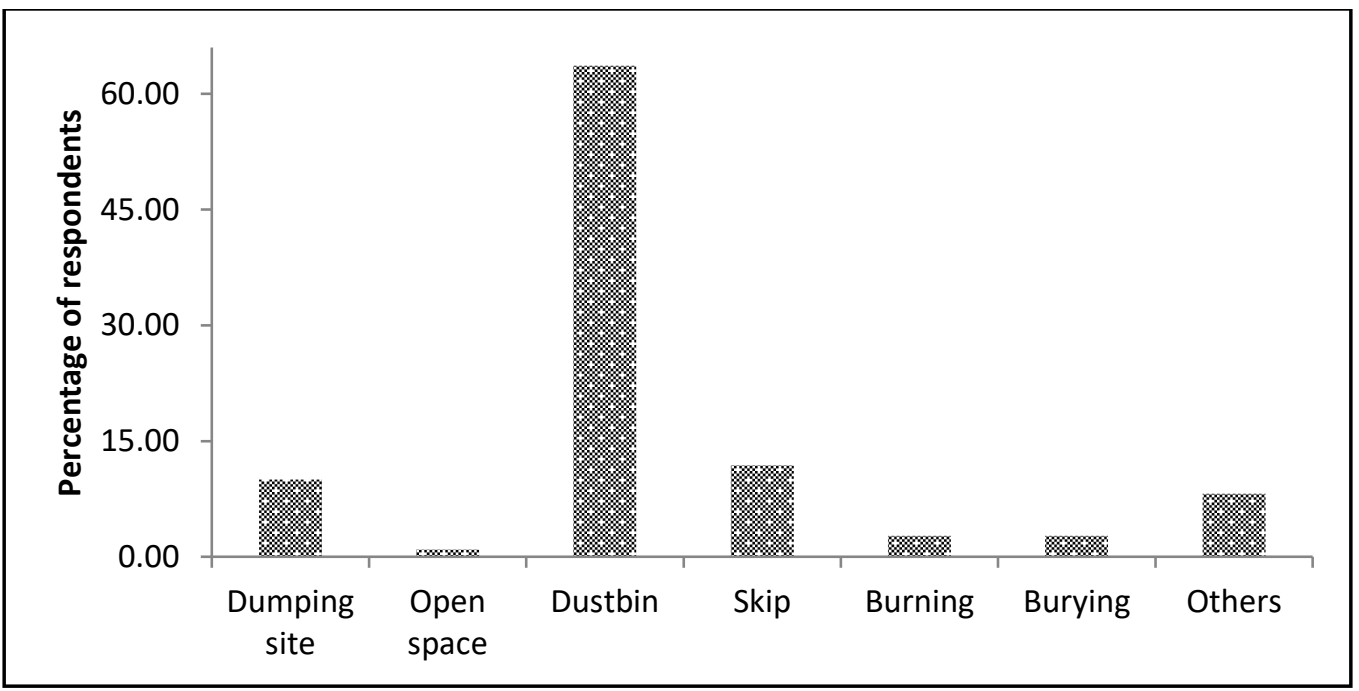

Figure (1) Methods of final disposal of plastic waste by households.

Furthermore, the underlying reasons for improper waste disposal included proximity of dumpsites, and skips to residence, absence of affordable alternatives and the limited operational catchment area of wastes collection companies in the municipality (Guerrero et al. 2013). Additionally, lack of education, poor attitudes and absence of environmental awareness, poverty and unguided waste disposal practices contribute to the indiscriminate dumping of garbage (Yoada et al. 2014) .

The possibility of an outbreak of cholera, diarrhoea and other environmental related diseases could be widespread in these areas due to improper solid waste disposal practices (Puopiel 2010). Indeed, statistics from the Ghana Health Service (GHS) 
showed that about $80 \%$ of all recorded cholera and diarrhea cases emanated from communities faced with waste management challenges (OwusuSekyere 2015).

Therefore, the distribution of dustbins to all households will ensure low patronage of informal solid wastes disposal whilst keeping the environment clean. It will also reduce the distance households travelled to access skip and dumpsite methods (Odonkor et al. 2020) which could reduce threat to the public health, with assurance of adequate sanitation (Guan et al. 2015).

\section{c. Collection and transportation}

Sanitary carting of municipal solid wastes has been the main challenge to most households and communities (Özbay 2015). These wastes accumulate in the municipality and become breeding grounds for rodents and flies who spread diseases and render dumpsites as health hazards (Ferronato \& Torretta 2019). For this reason, the collection, transportation and landfilling of domestic wastes remain a pivotal component of managing municipal solid wastes (Abdel-Shafy \& Mansour 2018).

The survey revealed two ways of collecting the wastes from the communities, these were the doorto-door and communal carting, (Figure 2), which involved the picking of wastes in dustbins placed in homes and skips placed in close proximity to communities respectively. Waste generators travelled distances to access skips in communities whilst they dump at their doorstep in the case of dustbin system. Door-to-door collection was predominant $(68.18 \%)$ in the study area and carried out by private companies, which indicates a wellplanned community with accessible roads for the easy transportation of the wastes. A few respondents, $(20.00 \%)$, had their wastes being collected by the communal method. This was prevalent in a small section of the study area. These communities had minimal accessible roads and so depended on the skip method of waste disposal that was managed by the municipal assembly. Also, $(11.82 \%)$ discarded their waste through other means such as self-lifting to dumping site, burning and burying. Inferences show that, the availability of dustbins to households corresponds to the doorto-door mode of collection, which means a reduction in large heaps of accumulated solid wastes and a decline in the breeding of rodents, insects and other unsanitary conditions at community dumpsites. For this reason, the use of dustbins in managing solid wastes is relevant for a successful process (Amanidaz et al. 2019; Chappells \& Shove 1999; Purkayastha et al. 2015).

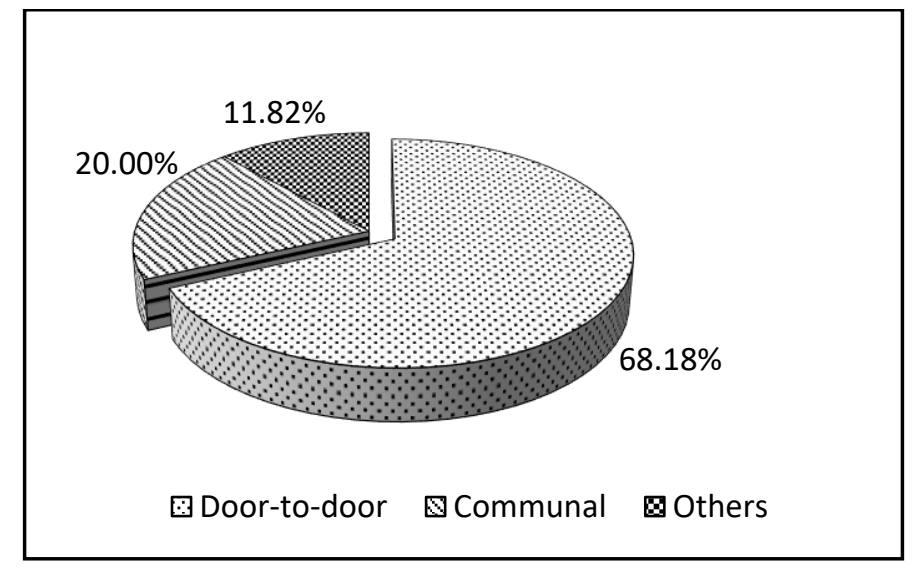

Figure (2) Mode of solid wastes collection. 
However, the cost of owning dustbins discouraged some respondents from depending on the them, and so they preferred the alternative means, such as skips, dumpsites open space dumping, burning and burying in the ground (Tweneboah \& Asomanin 2020). Even though the population in these brackets were few, the health effects may be significant.

\section{d. Challenges associated with household solid waste management}

According to (Kumar et al. 2017), knowledge of the threats to a successful solid waste management in households is required for an informed approach to the collection of the wastes and the recycle or reuse afterwards. Respondents were given the opportunity to state the challenges they face with waste management in the communities, these challenges were confirmed during the focus group discussions. Amongst the identified challenges were the Irregular collection of the plastic wastes, Scarcity and distance to Dumpsites, Lack of dustbins, and Lack of education, (Figure 3).

\section{$i$ Irregular collection of plastic wastes}

The regular waste collection was considered an important practice in waste management (Douti et al. 2017; Fagariba \& Song 2016). The survey revealed that, the irregular collection of plastic waste $(72.73 \%)$ served as a daunting task that required attention. Subsequently, the plastics wastes were mixed with the organics, which were then allowed to stand over unknown periods, with associated breeding of insects and rodents in the locality (Yoada et al. 2014). Further investigations attributed the situation to breakdown of collection vehicles, poor road network, large sized coverage area, limited resource allocation, and longer distances to landfill sites. These delays were predominant in the skip systems compared to use of dustbins, since the skips required special trucks to pick them for waste disposal, a situation that was consistent with the literature (Fagariba \& Song 2016; Miezah et al. 2015). This indicated that, the holistic development of a community through the provision of accessible road networks in addition to clean water and electricity supply contributes to the efficient collection of solid wastes in households.

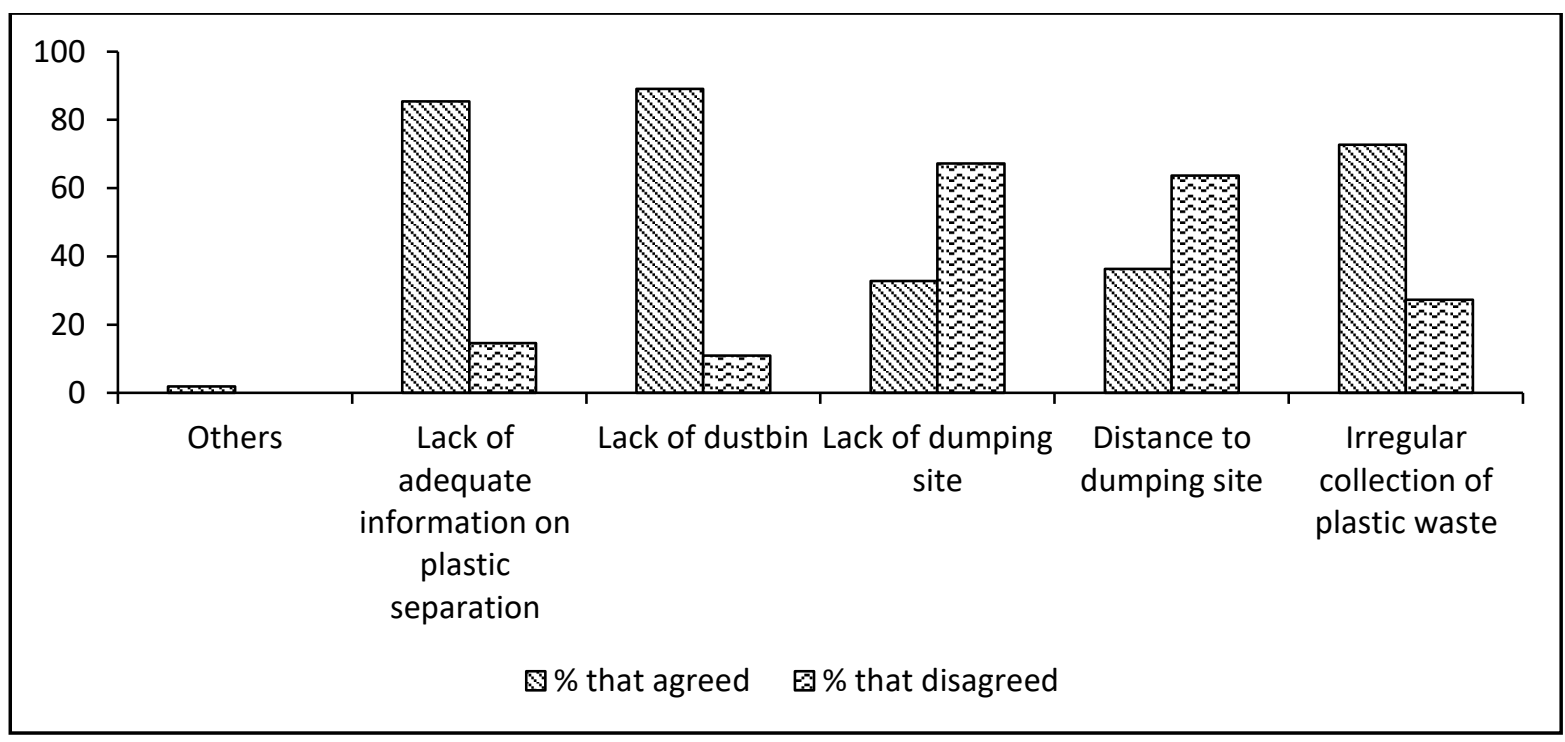

Figure (3) Challenges associated with municipal waste disposal. 


\section{ii. Scarcity and distance to Dumpsites}

The lack of dumpsites, and the longer distance of the available ones from households were found to be challenges to some homes even though not the majority. The $32.73 \%$ and $36.36 \%$ representing households that had no access to dumping sites and those that lived far away from the available sites respectively indicated that, a significant number of the population fell outside the municipal waste collection coverage. This contributed to indiscriminate dumping of wastes in the open gutters, burning and burying in the ground. On the other hand, the lack of dumpsites and closeness to skips was attributed to uncontrolled population growth and urbanization that paid little attention to land resources for wastes management (Ngoc \& Schnitzer 2009), a situation which was prevalent in other locations such as Bolgatanga (Miezah et al. 2015), and the Accra metropolis (Boadi \& Kuitunen 2003). Hence, there was the need for city authorities and developers to make provision for wastes disposal centers in communities to promote good sanitation and healthy living, without losing sight of the related hazards if not well managed, a situation that could mimick the Palestinian territory example (Al-Khatib et al. 2015).

\section{iii. Lack of dustbins}

The unavailability of dustbins for wastes collection by households was found to be widespread amongst respondents. The $89.09 \%$ households expressed the lack of sufficient dustbins for the temporal storage of wastes prior to the transportation to a landfill. These homes depended on the dustbin method of waste disposal and so found the available dustbins inadequate. This resulted in the overflow of existing ones, which created bad smell, food for scavenging animals, littering of the environment and health hazards (Bachok et al. 2020). The lack of resources experienced by waste collection companies hampered the distribution of free dustbins to most households who could not afford the purchase of such. The amount of wastes generated also increased with increasing urbanization (Gayanthika et al. 2019), for this reason, there was the need to encourage a dependence on multiple dustbins in collecting the wastes to protect the environment (Rohit et al. 2018). Additionally, the use of more than one dustbin could be adopted to promote source separation and recycling of wastes (Sheau-Tinga $\boldsymbol{e t}$ al. 2016). At least, a set of dustbins could be set aside for the collection of plastics or nondegradable wastes whilst the other becomes a receptacle for the food or degradable wastes. The popular response to the use of dustbins indicated that, the number of unwanted materials and items collected by the dustbin's method was qualitatively more than that of those collected by other means, and so it was more pressing to support household with free dustbins to maximize gains in managing wastes.

\section{iv. Lack of education}

Awareness creation is relevant in the waste management process since it enhances the understanding of waste generators and the collectors on the potential benefits and consequences (Hasan 2004). It also improves the generator-collector relationship through education on proper disposal and collection modes (Morar \& Bucur 2017). A knowledge of environmental cleanliness reduces the disposal of wastes into open gutters, burning and the burying in the ground. Hence, there was the need for local authorities to educate household and the public on good sanitation and environmental cleanliness for 
sustainable solid wastes management (Ghosh 2016).

Furthermore, households in LaNMMA demonstrated the lack of awareness on proper waste disposal, which was supported by $85.45 \%$ respondents (Figure 3). The unavailability of an educational program in the municipality to inform residents on good sanitation practices contributed to the unconventional disposal of the generated wastes. Similarly, the popularity of the mixed disposal method could be attributed to the lack of knowledge on source sorting of domestic wastes. Hence, an informative program in place will improve the separation of solid wastes in homes whilst minimizing mixed disposal with a subsequent increase in recycling rates.

\section{CONCLUSION}

This study shows a characterization of wastes generated in the municipality. It indicated that a larger portion of the waste is food wastes $(45.3 \%)$. This was followed by plastic wastes (17\%). It showed that the solid wastes were partly source sorted and partly mixed during disposal. The study results displayed that most households temporarily stored their wastes in dustbin prior to disposal and a few depended on skips, which were placed at a separate location in the communities. The door-todoor collection of the wastes was popular amongst respondents compared to the communal collection, which indicated a dependence on dustbins, and other vessels, which were easy to lift by the waste collecting companies. Those who disposed waste by the communal method had no option to the skips aside burning and open space dumping due to the inaccessible roads for wastes collection. Some of the identified challenges included long distances to dumpsites, lack of dustbins and the absence of an educational programme on environmental cleanliness as well as source separation.

Hence, it is proposed that an effective information dissemination on proper solid wastes disposal and source separation will improve the collection of the wastes. Furthermore, the distribution of free dustbins will lighten the financial burden on waste generators and enhance the source sorting by these households. Going by the findings, it is believed that the integration of recycling and landfilling of waste at the LaNMMA municipality will favor a shift towards a circular economy and therefore government should seek to create an enabling environment for such methods of managing the wastes. The implication in this study findings are that multidimensional intervention is critical as present compliance to the reforms is weak. The Assembly is required to strengthen the enforcement of the terms and conditions in the contract arrangements they have with the private sector. Composting of waste will provide huge benefits to the Assembly as the products from the process could be used as manure to boost agriculture in the area and elsewhere. This will also help provide employment opportunities for the teeming youth population who are searching for jobs.

\section{REFERENCE}

Yeboah A. B., Odei S., Anabila, E. (2019). A linear model for the collection of Institutional plastic wastes in Ghana: A case of the Council for Scientific and Industrial ResearchInstitute of Industrial Research (CSIR-IIR). Ghana Journal of Science, 60(2): 32-41. Doi: https://dx.doi.org10.4314/gjs.v60i2.4

Abalo E. M., Peprah P., Nyonyo J., AmpomahSarpong R., Agyemang-Duah W. (2018). A Review of the Triple Gains of Waste and the Way Forward for Ghana. Journal of Renewable Energy, 9737683. doi: $\underline{10.1155 / 2018 / 9737683}$ 
Abdel-Shafy H. I., Mansour, M. S. M. (2018). Solid waste issue: Sources, composition, disposal, recycling, and valorization. Egyptian Journal of Petroleum, 27(4): 1275-1290. doi: https://doi.org/10.1016/j.ejpe.2018.07.003

Abylkhani B., Guney M., Aiymbetov B., Yagofarova A., Sarbassov Y., Zorpas A. A., Inglezakis V. (2020). Detailed municipal solid waste composition analysis for Nur-Sultan City, Kazakhstan with implications for sustainable waste management in Central Asia. Environmental Science and Pollution Research, 5: 143-159. doi:10.1007/s11356-020-08431-x

Adansi-Bonah, E. (2016). Decentralisation at the La-Nkwantanang Madina Municipal Assembly challenged. Retrieved from: https://www.thefinderonline.com/editorial/item/ 2111-decentralisation-at-the-la-nkwantanangmadina-municipal-assembly-challenged, 07/09/2020. (07/09/2020).

Al-Khatib I. A., Abu Hammad A., Sharkas O. A., Sato C. (2015). Public concerns about and perceptions of solid waste dump sites and selection of sanitary landfill sites in the West Bank, Palestinian territory. Environmental monitoring and assessment, 187(4): 15732959.

doi:https://doi.org/10.1007/s10661-015-4401-1

Alfaia R. G. d. S. M., Costa A. M., Campos J. C. (2017). Municipal solid waste in Brazil: A review. Waste Management \& Research, 35(12): 1195-1209.

doi: $\underline{10.1177 / 0734242 X 17735375}$

Amanidaz N., Yaghmaeian K., Dehghani M. H., Mahvi A. H., Bakhshoodeh R. (2019). Households' behavior and socialenvironmental aspects of using bag dustbin for waste recovery in Tehran. Journal of Environmental Health Science and Engineering, 17(2): 1067-1076.

doi: 10.1007/s40201-019-00421-7
Amasuomo E., Baird J. (2016). The Concept of Waste and Waste Management. The Journal of Men's Studies, 6: 88-96. doi:10.5539/jms.v6n4p88

Amoah S. T., Kosoe E. A. (2014). Solid Waste Management in Urban Areas of Ghana: Issues and Experiences from Wa. Journal of Environment Pollution and Human Health, 2(5): 110-117. doi:10.12691/jephh-2-5-3

Ansah B. (2014). Characterization of municipal solid waste in three selected communities in the Tarkwa Township of Tarkwa Nsuaem Municipality in Ghana. (Master of Science in Environmental Science), Kwame Nkrumah University of Science and Technology, Manakin. (123456789/6605)

Ayilara M. S., Olanrewaju O. S., Babalola O. O., Odeyemi O. (2020). Waste Management through Composting: Challenges and Potentials. Sustainability, 12: 4456. doi:https://doi.org/10.3390/su12114456

Bachok, N., Salinah, O., Naing, N. N., \& Sarimah, A. (2020). Community Health Survey of Residents Living Near a Solid Waste Open Dumpsite in Sabak, Kelantan, Malaysia. International journal of environmental research and public health, 17: 311-324. doi:10.3390/ijerph17010311

Boadi K. O., Kuitunen M. (2003). Municipal Solid Waste Management in the Accra Metropolitan Area, Ghana. Environmentalist, 23(3): 211218 doi:10.1023/B:ENVR.0000017283.09117.20

Chappells H., Shove E. (1999). The dustbin: A study of domestic waste, household practices and utility services. International Planning Studies, 4(2): 267-280. doi:10.1080/13563479908721739

Cheng, K. H., \& Lin, J. J. M. (2013). Characteristics of Municipal Solid Waste (MSW) Composition of Two Different Cities in Taiwan. Advanced Materials Research, 807-809, 1185-1189. 
doi:https://doi.org/10.4028/www.scientific.net IAMR.807-809.1185

Diaz L. F. (2017). Waste management in developing countries and the circular economy. Waste Management \& Research, 35(1): 1-2.

doi: $\underline{10.1177 / 0734242 X 16681406}$

Douti N. B., Abanyie S. K., Ampofo S. (2017). Solid Waste Management Challenges in Urban Areas of Ghana: A Case Study of Bawku Municipality. International Journal of Geosciences, 8: 494-513. doi:10.4236/ijg.2017.84026

Fagariba C. J., Song S. (2016). Assessment of Impediments and Factors Affecting Waste Management: A Case of Accra Metropolis. Academia Journal of Environmental Science, 4(8): 144-162.

doi:10.20944/preprints201609.0012.v2

Ferronato N., Torretta V. (2019). Waste Mismanagement in Developing Countries: A Review of Global Issues. International journal of environmental research and public health, 16(6): 1060. doi:10.3390/ijerph16061060

Fobil J., Hogarh J. (2009). The dilemmas of plastic wastes in a developing economy: Proposals for a sustainable management approach for Ghana. West African Journal of Applied Ecology, 10(1): 1-8. doi:10.4314/wajae.v10i1.45716

Gayanthika W. A. L., Maduranga G. K. C. D., Silva A. I. S., Wikramarathne S. D. H. S., Ranasinghe R. M. I. S. (2019). Smart Dustbin for Waste Management. International Journal of Environmental Science and Development, 10(4): 118-121.

doi:10.18178/ijesd.2019.10.4.1159

Ghosh S. K. (2016). Sustainable SWM in Developing Countries Focusing on Faster Growing Economies, India and China. Procedia Environmental Sciences, 35: 176-184. doi:https://doi.org/10.1016/j.proenv.2016.07.07 $\underline{3}$
Guan Y., Zhang Y., Zhao D., Huang X., Li H. (2015). Rural domestic waste management in Zhejiang Province, China: Characteristics, current practices, and an improved strategy. Journal of the Air \& Waste Management Association, 65(6): 721-731. doi: $\underline{10.1080 / 10962247.2015 .1010751}$

Guerrero, L. A., Maas, G., \& Hogland, W. (2013). Solid waste management challenges for cities in developing countries. Waste Management, 33(1): 220-232.

doi:https://doi.org/10.1016/j.wasman.2012.09. $\underline{008}$

Hasan S. E. (2004). Public Awareness is key to successful waste management. Journal of Environmental Science and Health, Part A Toxic/Hazardous substances and Environmental Engineering, A39(2): 483-492. doi:10.1081/ESE-120027539

Kaoje A. U., Sabir A. A., Yusuf S., Jimoh A. O., Raji M. O. (2017). Residents' perception of solid waste disposal practices in Sokoto, Northwest Nigeria. African Journal of Environmental Science and Technology, 11(2): 94-102. doi:10.5897/AJEST2014.1791

Kumar S., Smith S. R., Fowler G., Velis C., Kumar S. J., Arya S., Cheeseman C. (2017). Challenges and opportunities associated with waste management in India. Royal Society open science, 4(3): 160764-160775. doi:10.1098/rsos.160764

Miezah K., Obiri-Danso K., Kádár Z., Fei-Baffoe B., Mensah M. Y. (2015). Municipal solid waste characterization and quantification as a measure towards effective waste management in Ghana. Waste Management, 46: 15-27. doi:https://doi.org/10.1016/j.wasman.2015.09. $\underline{009}$

Morar F., Bucur B. (2017). Raising Awareness on Waste Generation and Collection. Procedia Engineering, 181: 452-458. doi:https://doi.org/10.1016/j.proeng.2017.02.415 
Ngoc U. N., Schnitzer H. (2009). Sustainable solutions for solid waste management in Southeast Asian countries. Waste Management, 29(6): 1982-1995.

doi:https://doi.org/10.1016/j.wasman.2008.08.0 $\underline{31}$

Odonkor S. T., Frimpong K., Kurantin N. (2020). An assessment of house-hold solid waste management in a large Ghanaian district. Heliyon, 6(1): 30-40.

doi:https://doi.org/10.1016/j.heliyon.2019.e030 $\underline{40}$

Owusu-Sekyere E., Bagah D. A., Quansah J. Y. D. (2015). The Urban Solid Waste Management Conundrum in Ghana: Will It Ever End? World Environment, 5(2): 52-62.

doi: $\underline{10.5923 / \mathrm{j} . e n v .20150502 .02}$

Özbay İ. (2015). Evaluation of Municipal Solid Waste Management Practices for an Industrialized City. Polish Journal of Environmental Studies, 24(2): 637-644. doi:10.15244/pjoes/30933

Paritosh K., Yadav M., Mathur S., Balan V., Liao W., Pareek N., Vivekanand V. (2018). Organic Fraction of Municipal Solid Waste: Overview of Treatment Methodologies to Enhance Anaerobic Biodegradability. Frontiers in Energy Research, 6: 75-92. doi: $10.3389 /$ fenrg. 2018.00075

Puopiel F. (2010). Solid Waste Management in Ghana: The Case of Tamale Metropolitan Area. (Master of Science in Development Policy and Planning), Kwame Nkrumah University of Science and Technology, Manakin. (123456789/146)

Purkayastha D., Majumder M., Chakrabarti, S. (2015). Collection and recycle bin locationallocation problem in solid waste management: A review. Pollution, 1(2): 175-191. doi:10.7508/pj.2015.02.006

Rohit G. S., Chandra M. B., Saha S., Das D. (2018). Smart Dual Dustbin Model for Waste Management in Smart Cities. Paper presented at the $20183^{\text {rd }}$ International Conference for
Convergence in Technology (I2CT). http://dx.doi.org/10.1109/I2CT.2018.8529600

Sarbassov Y., Sagalova T., Tursunov O., Venetis C., Xenarios S., Inglezakis V. (2019). Survey on Household Solid Waste Sorting at Source in Developing Economies: A Case Study of NurSultan City in Kazakhstan. Sustainability, 11: 6496-6513.

doi: https://doi.org/10.3390/su11226496

Seth K., Cobbina S. J., Asare W., Duwiejuah A. B. (2014). Household Demand and Willingness to Pay for Solid Waste Management Service in Tuobodom in the Techiman-North District, Ghana. American Journal of Environmental Protection, 2(4): 74-78. doi:10.12691/env-2-4-3

Sharma K. D., Jain S. (2019). Overview of Municipal Solid Waste Generation, Composition, and Management in India. Journal of Environmental Engineering, 145(3): 18-35.

doi: 10.1061/(ASCE)EE.1943-7870.0001490

Sharma K. D., Jain S. (2020). Municipal solid waste generation, composition, and management: the global scenario. Social Responsibility Journal, 16(6): 917-948. doi:https://doi.org/10.1080/10643389.2011.569 $\underline{871}$

Sheau-Tinga L., Sin-Yeeb T., Weng-Wai C. (2016). Preferred Attributes of Waste Separation Behaviour: An Empirical Study. Procedia Engineering, 145: 738-745. doi: $\underline{10.1016 / j . p r o e n g .2016 .04 .094}$

Shen J., Zheng D., Zhang X., Qu M. (2020). Investigating Rural Domestic Waste Sorting Intentions Based on an Integrative Framework of Planned Behavior Theory and Normative Activation Models: Evidence from Guanzhong Basin, China. International Journal of Environmental Research and Public Health., 17: 4887-4904. doi: 10.3390/ijerph17134887

Tamrie Y. E., Hanna E. G., Argaw M. D. (2015). Determinants of Long Acting Reversible Contraception Method Use among Mothers in Extended Postpartum Period, Durame Town, 
Southern Ethiopia: A Cross Sectional Yoada R. M., Chirawurah D., Adongo P. B. (2014). Community Based Survey. Health, 7(10), 1315- Domestic waste disposal practice and 1325. doi:10.4236/health.2015.710146.

Tweneboah K. T., Asomanin A. K. (2020). Indiscriminate open space solid waste dumping behaviour of householders in the Brong-Ahafo perceptions of private sector waste management in urban Accra. BMC public health, 14(1): 697.

doi: $10.1186 / 1471-2458-14-697$

region of Ghana: a political economy analysis.

Cogent Environmental Science, 6(1): 1779553.

doi:10.1080/23311843.2020.1779553 